\title{
Erzurum İli Süit Sığırcılığı İşletmelerinin Mali Risk Analizi
}

\author{
Yavuz TOPCU \\ Atatürk Üniversitesi, Ziraat Fakültesi, Tarım Ekonomisi Bölümü, Erzurum, Türkiye \\ (*Sorumlu yazar e-mail: yavuztopcu@atauni.edu.tr) \\ DOI: 10.17097/ataunizfd.407159 \\ Geliş Tarihi (Received Date): 16.03.2018 \\ Kabul Tarihi (Accepted Date): 31.07.2018
}

\begin{abstract}
ÖZ: Bu çalışmanın amacı, Erzurum ili süt sığırcılığı işletmelerinin 2013-2014 cari dönem verilerine dayalı bilanço ve gelir-gider tablolarını oluşturularak, işletmelerin dönem sonu performanslarına dayalı risk düzeylerini belirlemektir. Bu amaç için Oltu, Narman, Pasinler ve Çat ilçelerinde 145 süt sığırcıllığ işletmesi ile yürütülen anketlerden elde edilen birincil veriler, araștırmanın ana materyali olușturmuștur. Bu verileri dikkate alarak, işletmelerin 2013-2014 üretim periyodu için bilanço ve gelir-gider tabloları hazırlanmış ve daha sonra faaliyet dönemi sonu için faaliyet ve karlılık oranları dikkate alan mali risk analizleri yapılmıștır. Araștırma sonuçları; Narman ve Pasinler ilçelerinde süt sığırcılığı ișletmelerinin faaliyetlerin sürdürülebilirliğ̣i açısından daha düşük ekonomik risklerle karşı karşıya olduğu, fakat sermaye devir oranının düşüklügünden dolayı potansiyel bir riske de işaret etmektedir. Ancak diğer ilçe işletmeleri faaliyet ve sermaye devir oranları arasındaki etkileşimin bir sonucu olarak, çok daha büyük risklerle karșı karşıyadır. Diğer taraftan süt sığırcılı̆̆ işletmelerinin faaliyet sonu karlılık oranları bakımından Narman ilçesi işletmeleri mutlak bir üstünlüğe sahip ve başarısının diğer ilçelerden çok yüksek olduğuna işaret edilmiştir. Dolayısıyla bütün işletmeler öz sermaye artırımı ile aktiflerde özellikle net işletme sermayesinde artış sağlayarak, orta ve uzun vadede süt sığırcılığı faaliyetini karlı ve sürdürülebilir kılabilirler.
\end{abstract}

Anahtar Kelimeler: Faaliyet ve karlılık oranları, Gelir-gider analizi, Risk analizi, Süt sığırcıllı̆̆ işletmeleri

\section{Financial Risk Analysis of Dairy Farms in Erzurum Province}

\begin{abstract}
The aim of this study is to determine the risk levels based on the performances of the dairy farms by creating the income and costs account tables including their current period data in Erzurum during 2013-2014. For this end, the primary data obtained from a survey conducted on 145 dairy farms in Oltu, Narman, Pasinler and Çat Districts were used for the main material of the study. The income and costs account tables for 2013-2014 production period of the dairy farms was created by taking into consideration these data, and then it were done financial risk analyses related to some operating and profitability rates associated with their management successes. The results of the study indicated that the dairy farms in Narman and Pasinler Districts in terms of their sustainable activities faced with lower economic risks, but pointed out a potential risk due to low capital turnover. However, the dairy farms in other districts faced with much greater risks as a result of the interaction between the operating and capital turnover. On the other hand, it was highlighted that the dairy farms in Narman District had an absolute advantage in view of the profitability ratios at the end of their activity, and that their successes were much higher than the others. All the dairy farms, therefore, could make it possible to perform a profitable and sustainable activity at the medium and long terms by increasing in their assets via their equities, especially net working capital.
\end{abstract}

Keywords: Operating and profitability rates, Income-cost analysis, Risk analysis, Dairy farms

\section{GİRİş}

Doğu Anadolu Bölgesi'nin en önemli hayvanc1lı faaliyet merkezlerinden Erzurum ilinin agroekolojik yapısı, tarım işletmelerinin bitkisel üretim faaliyeti ile sürekli faaliyet geliri temin etmelerine olanak sağlayamamaktadır. Dolayısıyla ișletmelere likidite sağlayarak y1l içerisinde ihtiyaçların karşılanmasına imkan sağlayan süt sığırcılığı faaliyeti, bölgenin çok kaliteli ve geniş mera alanları ile yem bitkileri yetiştiriciliği potansiyelinden dolayı nispi bir üstünlüğe sahiptir. Bütün bu avantajlarına rağmen süt sığırcılığı işletmelerinin küçük ölçeklerde olması hem kıt kaynakların etkin bir şekilde kullanımını engelleyerek üretim ve pazarlama maliyetlerinin etkinsiz kılınmasına hem de işletmelerin likidite ve rantabilite prensiplerini yerine getirememeleri, tarımsal faaliyetlerin sürdürülebilirliği ile ilgili doğal ve ekonomik risklere maruz kalmasına neden olmaktadır. Mevcut riskler altında karma tip tarım işletmelerinde en yüksek sermaye devir oranına sahip süt sığırcılığ 1 işletmeleri, yeterli tarımsal faaliyet geliri temin edemeyerek özellikle dönen aktiflerde yeterli artış sağlayamamaktadır (Topcu, 2005). Başka bir ifade ile üretimde kıt kaynakların etkinsiz kullanımından kaynaklanan başarısızlıkların yanında aktif ve pasif sermaye yapısı ve bileşimlerine dayalı olarak faaliyet sonu performanslarında önemli düşüşler yaşanmaktadır.

Süt sığırcılığı ișletmelerinin faaliyet sonu performanslarına dayalı teknik ve ekonomik yönetim başarısının bütünsel bir yaklaşımla analiz edilebilmesi, işletme düzeyinde verilerin temini yoluyla oluşturulacak sermaye kompozisyonu ve finans kaynakları ile kazanç analizlerini zorunlu kılmaktadır. Bu yüzden işletmelerin cari dönemde kullandıkları aktif değerler karşılığında yapılan faaliyet masrafları ve gelir bileşenlerinin belirlenerek, işletmelerin dönem sonu faaliyet 
başarısı üzerinde pozitif ve negatif etkiye sahip olan faktörlerin belirlenmesi büyük önem arz etmektedir. İşletmelerin faaliyet başarısı üzerinde etkili olan aktif varlıklar ile toplam üretim değeri üzerinde etkiye sahip olan masrafların optimum düzeylerinin belirlenmesi, işletmenin faaliyet başarısı için büyük bir önem taşımaktadır.

Stratejik öneme sahip olan bu faaliyet biriminin aktif ve pasif yapıları ile faaliyet sonu gelir ve gider analizlerini temel alan faaliyet risk ölçümlerinin yapılması hem işletmenin üretim planlaması ve organizasyon etkinliğine yönelik tedbirlerin alınmasına hem de işletmelerin bilanço değerleri arasındaki dengenin korunarak, masrafların minimum kılınmasına olanak sağlayabilir.

Bütün bu teknik ve ekonomik etkinliklere bağlı olarak, süt sığırcılı̆̆ı işletmelerinin ülke ekonomisi üzerindeki arz ve talep cephelerinde sağladıkları katma değerlerin pozitif etkilerinden de bahsetmek mümkündür. Mikro yaklaşımlarla ülke ekonomisi üzerinde süt sı ğırcılığı faaliyeti; istihdam hacminin genişletilmesinde, işgücünün dengeli bir şekilde kullanımında, daha rantabl bir çalışma ortamının sağlanmasında, gelir akımı ve dağılımındaki kesiklik ve dengesizliği gidermede, tarım işletmelerinde gıda maddesi niteliğinde olmayan ve endüstride ham madde olarak kullanılamayan tarımsal ürünleri değerlendirerek kaynak israfina engel olmada ve tarım sektöründe doğal ve ekonomik koşullardan kaynaklanan risk ve belirsizliği bertaraf etmede büyük bir öneme sahiptir (Aşkan ve Dağdemir, 2015; Topcu, 2005, 2008).

Özellikle mikro ölçekte tarımsal faaliyetler içerisinde süt sığırcılığı, sermaye devir oranı bağlı olarak likidite temininin zor olduğu dönemlerde işletme faaliyetlerinin sürdürülebilmesi, finansal sorumlulukların yerine getirilebilmesi ve aktiflerin teminat altına alınabilmesi bakımından hem ekonomik hem de sosyal açıdan çok büyük bir öneme sahiptir. Benzer şekilde ham sütün çeşitli süt ürünlerine işlenerek katma değeri yüksek ürünler haline dönüştürülmesi ve arz kıtlığının yaşandığ 1 dönemlerde piyasaya sunularak daha yüksek tarımsal gelirin elde edilmesi ile dönen aktif değerlerde artışın temin edilmesine de olanak sağlamaktadır.

Diğer taraftan makro yaklaşımla süt sığırcılı̆̆ faaliyeti; tarıma dayalı sanayiye hammadde sağlayarak bölgelerarası dengeli kalkınmaya yardımc1 olmak, bölgesel istihdama katkıda bulunarak kırsal kesimde yapısal ve gizli işsizliği önlemek ve kalkınmanın finansmanını öz kaynaklara dayalı yatırımlarla gerçekleştirme olanakları sunması bakımından da büyük bir etkiye sahiptir (Topcu, 2010). Ayrıca bu faaliyet birimi, yüksek sermaye devir oranları ile kırsal sosyoekonomik refahı yükselterek kırsal alandaki yaşam kalitesini artırmak, kırsal göçü önlemek ve dış ticaret yoluyla ülkeye döviz girdisi sağlayarak ödemeler dengesi üzerinde iyileştirici etkilere sahip olan önemli bir dinamizme sahiptir (Aral, 1989).

Ülke ekonomisindeki makro ve mikro yaklaşımlar altında süt sığırcılığının temel misyonu; insanoğlunun her yaş ve yaşam evresinde diyetlerin ana bileşeni ve hücrelerin de temel yapı taşını inşa eden gıda ürünlerinin orijin kaynağını oluşturan süt ve süt ürünlerinin tüketimine cevap verebilmek ve sağlıklı bireylerden oluşan bir toplum inşa edebilmek için bütün dünyada olduğu gibi milli gıda arz zinciri güvencesini sağlamaktır.

Bu misyon kapsamında 2000 yılında dünya süt üretimi 490 milyon ton iken, 2014 y1lında bu miktar 802 milyon tona yükselerek yıllık büyüme oran1 \%21 olmuştur. Dünya süt üretiminde Avrupa \%33 ile ilk sirada yer alırken, bunu Asya \%29 ve Amerika \%28'lik paylarla takip etmektedir (FAOSTAT, 2017). Dünya süt üretiminde lider ülkelerin payları dikkate aldığı zaman; ABD \%12, Hindistan \%8, Çin $\% 5$, Brezilya \%4,4, Almanya \%3,9, Rusya \%3,8'lik nispetler ile katkı sağlarken; Türkiye ise \%2'lik bir oran ile onuncu sirada yer almaktadır (FAOSTAT, 2017; TÜİK, 2017).

Türkiye süt üretiminin $\% 85$ 'ini oluşturan (TEPGE, 2014) süt sığırcılığı işletmelerinde en önemli niteliksel aktif değer olarak kabul edilen süt sığırı varlığının genotiplerine göre sayıları ve faaliyet getirisinin temel kaynağı süt üretim miktarları, Çizelge 1'de verilmiştir. Kültür ve melez ırkların süt sığırı varlıklarında yıllık ortalama $\% 13,3$ ve $\% 0,9$ oranlarında artış sağlanırken, yerli ırklarda \%3,9 oranında bir azalış trendi gözlenmiştir.

Süt sığırlarının genotiplerindeki değişimlere karşı; son yıllarda kültür, melez ve yerli sığırlar başına ve ortalama süt verimleri sırasıyla 3,7, 2,7, 1,3 ve 3,1 ton olarak hesaplanmıştır. Türkiye'nin sığır başına ortalama süt verimi, dünya ortalaması olan 2,5 tondan yüksek olmasına rağmen; dünya süt üretiminde lider ülkelerden $\mathrm{ABD}$, Almanya ve Rusya'nın sirasiyla 10,1, 7,5, 4,0 ton verimlerinden düşüktür. Fakat süt üretiminde lider Çin (2,9 ton), Brezilya (1,5 ton) ve Hindistan'daki (1,4 ton) sığır başına süt verimlerinden daha yüksektir (FAOSTAT, 2017). Diğer taraftan; Türkiye'nin toplam süt üretimi yaklaşık 17 milyon ton olup, ortalama yıllık artış oranı $\% 8,3$ 'dür. 
Çizelge 1. Türkiye'de sağılan süt sığırı varlığı (adet) ve süt üretim miktarı (ton)

\begin{tabular}{ccccccc}
\hline \multirow{2}{*}{ Yıllar } & \multicolumn{2}{c}{ Sığır (Kültür) } & \multicolumn{2}{c}{ Sı̆̆ır (Melez) } & \multicolumn{2}{c}{ Sığır (Yerli) } \\
\cline { 2 - 7 } & Hayvan sayıs & Süt üretimi & Hayvan sayıSı & Süt üretimi & Hayvan sayısı & Süt üretimi \\
\hline \hline 2002 & 850725 & 2467889 & 1971740 & 3867656 & 1570103 & 1155088 \\
2003 & 1034817 & 3215859 & 2236680 & 4568252 & 1768865 & 1730027 \\
2004 & 832711 & 3231461 & 1699804 & 4608293 & 1343206 & 1769571 \\
2005 & 925618 & 3596017 & 1717309 & 4646857 & 1355170 & 1783328 \\
2006 & 1106679 & 4295367 & 1799409 & 4884590 & 1281843 & 1687345 \\
2007 & 1299750 & 5050533 & 1698801 & 4608728 & 1230889 & 1620079 \\
2008 & 1385730 & 5380715 & 1665189 & 4520465 & 1029324 & 1353996 \\
2009 & 1470886 & 5713004 & 1686064 & 4585859 & 976198 & 1284450 \\
2010 & 1626412 & 6309065 & 1787012 & 4861835 & 948417 & 1247644 \\
2011 & 1868274 & 7239644 & 1962713 & 5341224 & 930155 & 1221560 \\
2012 & 2211242 & 8544402 & 2263400 & 6166762 & 956758 & 1256673 \\
2013 & 2314278 & 8946131 & 2395897 & 6531573 & 897097 & 1177305 \\
2014 & 2427909 & 9383812 & 2428708 & 6628337 & 752623 & 986701 \\
2015 & 2500880 & 9672573 & 2314061 & 6315366 & 720833 & 945581 \\
2016 & 2542163 & 9825300 & 2235501 & 6101826 & 654051 & 859137 \\
\hline
\end{tabular}

(Kaynak: TÜİK, 2017)

Araştırma bölgesini kapsamı içine alan Kuzeydoğu Anadolu bölgesi, doğal kaynaklar ve agroekolojik özellikler bakımından hayvancılık faaliyetine daha elverişlidir. Bu bölgedeki tarım işletmelerinin büyük bir çoğunluğu karma tip işletmelerden oluşurken; bitkisel üretimde daha çok yem bitkileri yetiştiriciliği ve hayvancılık faaliyetinde ise besicilik ve süt sığırcılığı ön plana çıkmaktadır. Araştırma bölgesindeki karma tip işletmelerin toplam işletmeler içerisindeki payı \%87'dir. Diğer taraftan yalnızca bitkisel ve yalnızca hayvansal üretim yapan işletmeler sırasıyla \%11 ve $\% 2$ 'lik paylara sahiptir (Topcu, 2008).

Erzurum'daki karma tip tarım işletmeleri, Türkiye'deki karma tip işletmelerin yaklaşık
$\% 2,5$ 'ini temsil ederken (Topcu, 2005); süt sığırı varlığının \%4,6'sını ve süt üretiminin de \%4,4'ünü oluşturmaktadır (TUİK, 2017). Erzurum süt sığırcılığı işletmelerinin kültür ve melez ırk hayvan varlıklarında y1llık ortalama $\% 17,2$ ve $\% 9,3$ 'lük artışlar sağlanırken, yerli ırklarda \%5,9'luk bir azalış trendi gözlenmiştir. Türkiye süt sığırcılığı işletmelerine göre, Erzurum'daki süt sığırı ırklarında yaşanan değişim trendlerindeki iyileşmelere rağmen; kültür, melez ve yerli ırk süt ineği başına verimler sırasılyla $3,7,2,9$ ve 1,3 ton ile dikkate değer bir değişme gözlenmezken, ortalama süt verimi 2,9 ton ile daha düşük düzeylerde seyretmektedir (Çizelge 2).

Çizelge 2. Erzurum'da sağılan süt sığırı varlığı (adet) ve süt üretim miktarı (ton)

\begin{tabular}{|c|c|c|c|c|c|c|}
\hline \multirow{2}{*}{ Yillar } & \multicolumn{2}{|c|}{ Sığır (Kültürr) } & \multicolumn{2}{|c|}{ Sığır (Melez) } & \multicolumn{2}{|c|}{ Sığır (Yerli) } \\
\hline & Hayvan sayısı & Süt üretimi & Hayvan sayısı & Süt üretimi & Hayvan sayısı & Süt üretimi \\
\hline 2002 & 9462 & 226294 & 83347 & 148859 & 151876 & 1112084 \\
\hline 2003 & 8529 & 22288 & 89437 & 170825 & 152343 & 168797 \\
\hline 2004 & 6454 & 23963 & 60375 & 175691 & 115723 & 151365 \\
\hline 2005 & 6518 & 24212 & 53265 & 155000 & 119227 & 155949 \\
\hline 2006 & 6667 & 24758 & 68124 & 198239 & 91317 & 119443 \\
\hline 2007 & 5829 & 21646 & 66360 & 193107 & 106632 & 139475 \\
\hline 2008 & 8530 & 31677 & 87653 & 255068 & 70056 & 91633 \\
\hline 2009 & 14231 & 52862 & 121338 & 353093 & 61924 & 80996 \\
\hline 2010 & 15809 & 58712 & 120302 & 350079 & 58862 & 76991 \\
\hline 2011 & 18184 & 67530 & 140052 & 407549 & 53901 & 70501 \\
\hline 2012 & 24955 & 92683 & 164228 & 477899 & 46742 & 61138 \\
\hline 2013 & 30012 & 111460 & 198284 & 577010 & 26853 & 35124 \\
\hline 2014 & 29666 & 110185 & 197717 & 575353 & 21953 & 28715 \\
\hline 2015 & 31101 & 115509 & 190952 & 555668 & 21060 & 27544 \\
\hline 2016 & 33859 & 125758 & 199115 & 579422 & 18700 & 24457 \\
\hline
\end{tabular}

(Kaynak: Anonim, 2017) 
Erzurum ilindeki süt sığırı varlığı kültür ve melez ırklar lehinde önemli artış sergilerken; süt veriminin dolayısıyla süt sığırcılığ faaliyetinden elde edilen brüt üretim değerinin düşük düzeylerde teşekkül etmesi, yetiştiricilerin faaliyet başarısını ve yönetim motivasyonlarını önemli ölçüde düşürmektedir. $\mathrm{Bu}$ başarısızlıkların temel nedenleri arasında süt sığırlarının çevre şartlarına iyi adapte olamaması, hayvan barınakları ve diğer binaların kapasite ve yapısal niteliklerinin uygunsuzluğu (Aydın ve ark., 2016; Koçyiğit ve ark., 2016), kesif yemlerin rasyon ve likid varlıkların da dönen aktifler içerisindeki paylarının çok düşük olması (Aşkan ve Dağdemir, 2016; Çelik ve ark., 2016; Hazneci ve Ceyhan, 2011; Direk ve Bayramoğlu, 2007), bakım ve besleme programlarının yetersizliği (Topcu ve ark., 2016; Kızılay ve Akçaöz, 2008) ve işletme yönetimi ve organizasyonu ile ilgili aksaklıkların yer aldığı (Topcu, 2008) rapor edilmiştir.

Rapor edilen aksaklıklarla ilişkili olarak araştırma bölgesinde süt sığırcılığı işletmelerinin sabit varlıklarının toplam aktifler içerisinde payının $\% 85$ 'ler düzeyinde olması (Topcu, 2015); işletmelerin üretim dönemi içerisinde yüksek bakım ve onarım masrafları ile daha yüksek amortismanlara maruz kalmasına, likid değerlerin yatırımlara bağlı kalmasına ve üçüncü kişilere karşı sorumlulukların daha yüksek maliyetlerle yerine getirilebilmesine sebebiyet vermektedir. Diğer taraftan malzeme ve mühimmat ile likid varlıkları teşkil eden dönen varlıkların miktarlarının yetersizliği, üretim faaliyetinin teknik ve ekonomik optimum düzeylerde gerçekleşmesini de engellemektedir (Topcu, 2015). Sonuç olarak, duran aktiflerin atıl kalması ve dönen varlıkların ise optimumdan uzak kullanılması hem üretim maliyetlerinin yükselmesine hem de daha düşük hasılat ile çalışılmasına neden olmaktadır.

Bütün bu olumsuzluklar karşısında süt sığırcılığı faaliyetinin sürdürülebilirliği ve başarılı bir faaliyet performansının gerçekleştirebilmesi, işletmecilerin yalnız aktif ve pasif planlaması ile değil aynı zamanda çok sayıda girdinin işletmeye minimum maliyetle tedarik fonksiyonun icrasını gerekli kılmaktadır. Diğer taraftan iyi bir yönetim ve sevk fonksiyonu ile bu aktiflerin faaliyet birimlerine teknik ve ekonomik optimum seviyelerde veya eşit marjinal gelirler prensibine göre tahsislerin yapılması kaçınılmazdır.

$\mathrm{Bu}$ temel işletmecilik fonksiyonları altında süt sığırcılığı işletmelerinin faaliyet başarısını belirlemek için aktif değerler ile yetiştiricilik sürecinde maruz kalınan masraflar arasındaki ilişkilere bağlı olarak, dönem sonu faaliyet oranları ve rantabilite düzeylerinin ayrıntılı bir şekilde analiz edilmesi zorunluluk arz etmektedir. $\mathrm{Bu}$ yüzden belirlenen hedefler doğrultusunda, Erzurum ilinde süt sı ğırcılığı yapan işletmelerin aktif ve pasif varlıkları ile faaliyet gelir ve giderleri dikkate alınarak; işletmelerin faaliyet sonu performans başarısı ve sürdürülebilirliği bakımından faaliyet ve rantabilite oranlarına dayalı risklerin ölçülmesi amacıyla, bu çalışma planlanmıştır.

\section{MATERYAL VE METOT}

\section{Materyal}

Araştırmanın ana materyalini Erzurum ilinin agro-ekolojik tarımsal alt bölgelerini temsil etme niteliği taşıyan I. alt bölgeden Oltu, II. alt bölgeden Narman, III. alt bölgeden Pasinler ve IV . alt bölgeden Çat İlçelerinde, 2013-2014 üretim döneminde faaliyetlerini sürdüren süt sığırcılığı işletmelerinin sahipleri ile yüz yüze yapılan anket verilerinden elde edilen birincil veriler oluşturmuştur. Ayrıca ikincil veriler, Erzurum ve ifade edilen ilçelerin Gıda, Tarım ve Hayvancılık Müdürlükleri, çeşitli istatistiki kurum ve kuruluşların (TUIK, FAO) verileri ile yerli ve yabancı bilimsel makale, rapor ve araştırma sonuçlarından sağlanmıştır.

\section{Metotlar}

\section{Örnek büyüklüğ̈̈̈nün belirlenmesinde uygulanan metot}

Erzurum ilinin agro-ekolojik tarımsal özellikleri dikkate alınarak; her bir tarımsal alt bölgeyi temsil etme niteliği taşıyan ve fiili olarak süt sığırcılı̆̆ yapan, süt sığırı varlığı 5 ve üstü baş hayvana sahip işletmelerin süt sığırı varlıklarına göre (Anonim, 2013); tarımsal alt bölgeleri temsil etme niteliği taşıyan I. alt bölgeden Oltu, II. alt bölgeden Narman, III. alt bölgeden Pasinler ve IV. alt bölgeden Çat İlçeleri ile bunlara bağlı köyler Gayeli Örnekleme Yöntemi, süt sığırcılı̆̆ı yapan işletmeler ise Basit Tesadüfî Örnekleme Yöntemleri ile seçilmiştir. Araştırma bölgesinde süt sığırcığı yapan işletmelerin süt sığırı varlıkları dikkate alınarak; ana ve örnek kitleler için bulunan ortalama, standart sapma ve varyanslara dayalı olarak, örnek büyüklüğü aşağıdaki eşitlikle hesaplanmıştır (Topcu, 2012).

$$
n=\left(\frac{N \cdot Z_{\alpha / 2}^{2} \sigma^{2}}{(N-1) d^{2}+Z_{\alpha / 2}^{2} \sigma^{2}}\right)
$$

$n$ : Örnek kitle büyüklüğü,

$N$ : Ana kitle büyüklüğ̈̈ (2042 işletme),

$Z_{\alpha / 2}: \mathrm{Z}$ tablosunda $\alpha / 2$ ihtimal düzeyindeki cetvel değeri $(1,96)$,

$\sigma^{2}$ : Ana kitlenin varyansı $(162,8)$,

$\mu$ : Ana kitle ortalaması $(15,4)$, 
$\bar{x}:$ Örnek kitle ortalaması $(17,5)$,

$d$ : Ana kitle ortalaması $(\mu=15.4)$ ve örnek ortalaması $(\bar{x}=17.5)$ arasında izin verilen sapma miktarını $(d=\bar{x}-\mu)$ ise $\mathrm{d}=(17,5-15,4)=$ 2.10 olarak belirlenmiştir.
Bütün bu veriler 1şında örnek büyüklüğü (n) 132 olarak hesaplanmıştır. Fakat veri toplama aşamasında herhangi bir problemle karşılaşılma ve verilerin geçersizliği ihtimaline karşı 145 anket ile çalışma yürütülmüştür. Anketlerin agro-ekolojik alt tarım bölgelerindeki ilçelere dağılımı, Çizelge 3'de verilmiştir.

Çizelge 3. Alt tarım bölgelerini temsil eden ilçelerdeki işletme sayıları ve yapılan anket sayıları

\begin{tabular}{llcc}
\hline Tarım bölgeleri & İlçe & İşletme sayısı & Yapılan anket sayısı \\
\hline \hline I. Alt bölge & Oltu & 142 & 20 \\
II. Alt bölge & Narman & 507 & 69 \\
III. Alt bölge & Pasinler & 204 & 28 \\
IV. Alt bölge & Çat & 208 & 28 \\
\hline Toplam & & $\mathbf{1 0 6 1}$ & $\mathbf{1 4 5}$ \\
\hline Genel Toplam & & $\mathbf{2 0 4 2}$ & - \\
\hline
\end{tabular}

\section{Anket verilerinin elde edilmesinde uygulanan metot}

Anket verilerinin temin edilmesi için hazırlanan anket formları, üç ana faktör değişkeni adı altında toplanmıştır. Bunlardan birincisi, süt sığırcılı̆̆ yapan işletmecilerin demografik yapı değişkenleri; ikincisi, süt sığırcılığı işletmelerinin aktif ve pasif sermaye yapı bileşenleri ve sonuncusu süt sığırcılığı işletmelerinin tarımsal yapı ve üretim değişkenlerinden oluşmaktadır.

\section{Verilerin ekonomik analizinde uygulanan metotlar}

Bilanço tablolarına kayıt edilen aktif değerler; cari dönem piyasa değeri metodu ile değerlendirilmiş ve duran varlıkların ekonomik faaliyetlerde kullanım sürelerine intikal ettirilmiş amortisman payları düşülerek, net duran varlıklar olarak kayıt edilmiştir. Bina ve makine amortismanları sırasıyla $\% 4$ ve $\% 10$ olarak alınırken (Topcu, 2005), süt inekleri için ortalama laktasyon süresi 7 dönem olarak kabul edilmiş (Selvi ve Yanar, 2016) ve süt ineğinin piyasa değeri bu süreye bölünerek hesaplanmıştır. Pasif değerlerde yer alan borçlar ise çiftçilerin beyanlarına göre kayıt edilmiştir.

Hesaplanan amortisman payları, cari dönemde ilgili aktif değerin üretimde kullanım karşılığı olarak gelir-gider cetvelinde faaliyet masraflarına aktarılırken; duran varlıkların yıllık rutin ve cari dönem arızi bakım-onarım masrafları, ilgili aktif değerlerin ortalama \%3 ve \%2'si (Kıral ve ark., 1999) kadar alınmış ve cari masraflara akaryakıt masrafları da dahil edilmiştir. Diğer taraftan süt ineklerinin doğumu ve yıl sonunda ise dana ve düvelerin çă̆ değişimleri sonucunda farklı yaşam evlerine geçişle oluşturulmuş olan envanter kıymet artışları, gelirlere; fakat kayıp ve ölümler ise masraflara kayıt edilmiştir. Faaliyet gelirleri arasında süt satışları ile süt ürünlerine işlenen ürünlerin değerleri, diğer tarımsal faaliyet gelirleri ise gübre satış değerleri ile işletme varlıklarının başka işletmelere kullandırılma karşılık değerleri ve yem bitkileri üretim değerlerinden oluşan üretim değerleri de süt sığırcılığı faaliyet gelirleri olarak kayıt edilmiştir.

Süt sığırcılığı işletmelerinin bilanço ve kazanç tablolarına dayalı risk analizleri ile işletmelerin finansal faaliyet başarısı ve sürdürülebilirliği olanakları değerlendirilmiştir. $\mathrm{Bu}$ amaçlar için kullanılan faaliyet ve karlılık oranları:

1. Faaliyet oranı (AT), işletmelerin bir faaliyet döneminde gerçekleştirmiş oldukları toplam masraflar karşılı̆̆ında elde etmiş oldukları Gayri Safi Üretim Değerini (GSÜD) ifade etmektedir (İnan, 2001).

2. Sermaye devir oranı (CT), faaliyet biriminin toplam aktifleri karşılı̆̆ında meydana getirmiş olduğu GSÜD'ni göstermektedir (Bolak, 2008).

3. Öz sermaye devir oranı (ET), işletmenin öz sermayesinden sağladı̆̆ $ı$ GSÜD'dir (Ilgaz, 2017).

4. Net işletme sermayesi devir oranı (NWCT), net işletme sermayesi karşılığında meydana getirilen GSÜD'ni ifade etmektedir (Er, 2009).

5. Dönen varlıklar devir oranı (CAT), dönen işletme aktifleri karşılı̆̆ında să̆lanan GSÜD'dir (Ilgaz, 2017).

6. Net maddi duran varlıklar devir oranı (TFAT), net sabit işletme aktifleri karşılığında elde edilen GSÜD olarak tanımlanır (Köseoğlu, 2017).

7. Brüt kar (GP), işletmelerin faaliyetleri sonucunda elde ettikleri GSÜD'den faaliyet değişir masrafların çıkarılması ile hesaplanan bir orandır (Торси, 2004). 
8. Brüt kar marjı (GPM), GSÜD karşılı̆̆ında elde edilen brüt karın nispi oranıdır (Bolak, 2008).

9. Net kar marjı (NPM), GSÜD karşılı̆̆ında kazandırlan vergi öncesi kar (VÖK)'in nispi oranıdır (Er, 2009).

10. Devamll sermaye karlıliğl (ROLTS), Uzun vadeli borçlar ile öz sermaye karşılığında VÖNK'ın nispi payıdır (Ilgaz, 2017).

11. Mali rantabilite (FP), işletmelerin $\ddot{o z}$ sermaye karşılı̆̆ında faaliyetlerinde săgladıkları faiz ve vergi sonrasi net karın (FAVSNK) nispi olarak ifadesidir (Çelik ve ark., 2016).

12. Ekonomik rantabilite (EP), işletmelerin toplam aktifleri karşılığında sağladıkları faiz ve vergi öncesi nispi kar (FAVÖK)'dır (Çetin, 2008).

Çizelge 4. İşletmeci ve ailelerinin demografik özellikleri

\begin{tabular}{|c|c|c|c|c|c|c|c|c|c|c|}
\hline \multirow{2}{*}{ İlçeler } & \multirow{2}{*}{$\begin{array}{c}\text { İşletme } \\
\text { Sayısı }\end{array}$} & \multicolumn{5}{|c|}{ İşletmeci } & \multicolumn{4}{|c|}{ Aile } \\
\hline & & Yaş & Eğitim süresi & TFUY & SSUY & SGK & AİB & TYKI & KDİS & TDG \\
\hline Oltu & 20 & 46,2 & 8 & 27,7 & 24,8 & 10 & 4,4 & 39,2 & 0 & 9500 \\
\hline Narman & 69 & 47,5 & 8 & 28,3 & 25,8 & 43 & 5,6 & 44,3 & 5 & 9775 \\
\hline Pasinler & 28 & 49,2 & 7 & 35,6 & 32,2 & 25 & 4,9 & 45,0 & 3 & 16300 \\
\hline Çat & 28 & 45,9 & 9 & 28,9 & 27,2 & 11 & 5,9 & 42,9 & 6 & 12642 \\
\hline Toplam & 145 & $\mathbf{4 7 , 3}$ & 8,5 & 29,8 & 27,2 & 89 & $\mathbf{5 , 4}$ & 43,5 & 4,7 & 12197 \\
\hline
\end{tabular}

İşletmecilerin tüm y1l köyde ikamet süreleri (TYKİ), 43,5 y1l ve y1l boyunca tam zamanlı (\%97) köyde ikamet etmektedir. Tarımsal faaliyetin en düşük düzeylerde seyrettiği kış aylarında, ailelerin \%3'ü kısmi zamanlı 4,7 ay köy dışında ikamet (KDIS) etmektedirler. Ayrıca işletmecilerin yıllık tarım dışı gelirleri (TDG) 12197 TL'dir (Çizelge 4).

Süt sığırcılığı işletmelerinde çeşitli aktif değerler ve masraf bileşenleri

Süt sığırcılığ sermaye kompozisyonu ve değerleri ile ilgili sabit ve cari masraflar, Çizelge 5 ve Çizelge 6'da verilmiştir. Süt sığırcılığı işletmelerinde hayvan barınakları 13 yıldan daha fazla sürede kullanılmasına rağmen, Çat ilçesinde barınaklar 9 yıllık kullanım ile daha yeni ve en yüksek piyasa değeri ve sabit masrafa sahiptir (Çizelge 5). Diğer taraftan makine envanteri bakımından en yüksek makine değeri ve yeni makinelere sahip olan Narman ilçesi, en yüksek sabit makine masraflarına maruz kalmaktadır (Çizelge 6).

Süt sığırcılığı işletmelerinde hayvan sermayesi ile envanter değeri, Çizelge 7 ve yem sermayesi ile

\section{BULGULAR VE TARTISSMA}

\section{Süt sığırcılığı işletmelerinde demografik ve sosyoekonomik yapı}

Erzurum ilinde süt sığırcılığı yapan işletmelerin demografik ve sosyoekonomik yapısı ile ilgili veriler, Çizelge 4'de özetlenmiştir. İşletmecinin yaş ortalaması 47,3 olup, orta öğretim mezunları daha baskındır. İşletmecilerin tarımsal (TFUY) ve süt sığırcılığı faaliyeti uğraş yılları (SSUY), 29,3 ve 27,2 yıl olarak hesaplanmıştır. Sosyal güvenlik kurumuna (SGK) kayıtlı işletmeciler, toplam işletmecilerin $\% 61,4$ 'ünü oluşturmuştur. Erzurum ili süt sığırcılığ işletmelerinde ortalama aile büyüklüğü (AIB 5 ) 5,4 birey olup, Çat ve Narman ilçelerindekiler il ortalamasının üzerindedir. masrafları, Çizelge 8 'de verilmiştir. Kültür ve melez ırk süt sığırı varlığının en yüksek olduğu Oltu ilçesi, 26 ve 16,8 baş ile Erzurum ortalamasından daha yüksek bir paya sahiptir. Yerli süt sı̆̆ır varlığı en fazla Narman ilçesinde olmasına rağmen, toplam sığır sayısı ve hayvan envanter değerinde en yüksek paya sahiptir.

Yarı entansif sistemde faaliyet sürdüren süt sığırı işletmelerinde hayvan başına günlük tüketilen kaba ve kesif yem miktarları ve günlük yem envanter değeri bakımında en yüksek pay, 95,50 ve $28,20 \mathrm{~kg}$ rasyon ve 18194 TL ile Narman ilçesine aittir. İşletmelerde hayvan başına tüketilen günlük kaba ve kesif yem tüketim miktarları için Erzurum il ortalamas1, 54,26 ve 22,31 kg olup; rasyon envanter değeri ise 15493 TL'dir (Çizelge 8).

Süt sığırlarının sağlık, bakım ve diğer cari masrafları ise Çizelge 9'da verilmiştir. En yüksek sağlık ve bakım masrafları Oltu ve Pasinler İlçelerinde, fakat en düşük sağlık ve bakım masrafları da Narman ilçesinde gerçekleşmiştir (Çizelge 9). 
Erzurum İli Süt Sığırcılığg İşletmelerinin Mali Risk Analizi

Çizelge 5. Bina varlığı, nevi, değeri ve masrafları (TL)

\begin{tabular}{|c|c|c|c|c|c|c|c|}
\hline \multirow[b]{2}{*}{ Bina nevi } & \multicolumn{6}{|c|}{ OLTU } & \multirow[b]{2}{*}{$\begin{array}{c}\text { Cari Dönem } \\
\text { Masraf }\end{array}$} \\
\hline & $\begin{array}{c}\text { Alan } \\
\left(\mathbf{m}^{2}\right)\end{array}$ & $\begin{array}{l}\text { Yaş } \\
\text { (yıl) }\end{array}$ & $\begin{array}{l}\text { Değeri } \\
\text { (TL) }\end{array}$ & $\begin{array}{c}\text { Amortisman } \\
(\mathbf{T L})^{*}\end{array}$ & $\begin{array}{c}\text { Yıllık Onarım } \\
\text { Bakım } \\
\text { Masrafı } \\
\end{array}$ & $\begin{array}{c}\text { Toplam Sabit } \\
\text { Masraf }\end{array}$ & \\
\hline $\mathrm{Ev}$ & 125,00 & 11,50 & 38250 & 1530,00 & 1794,12 & 3324,12 & 843,75 \\
\hline Garaj & 36,25 & 14,00 & 8125 & 325,00 & 500,00 & 825,00 & 250,00 \\
\hline Ahir & 216,30 & 11,70 & 30750 & 1230,00 & 2531,25 & 3761,25 & 1500,00 \\
\hline Samanlık & 110,32 & 12,26 & 13474 & 538,96 & 500,00 & 1038,96 & 0,00 \\
\hline Sulama Kanalı & 50,00 & 10,00 & 13000 & 520,00 & 1500,00 & 2020,00 & 0,00 \\
\hline Toplam & $\mathbf{5 3 7 , 8 7}$ & & 103599 & 4143,96 & 6825,37 & 10969,33 & 2593,75 \\
\hline \multicolumn{8}{|c|}{ NARMAN } \\
\hline Bina nevi & $\begin{array}{c}\text { Alan } \\
\left(\mathbf{m}^{2}\right)\end{array}$ & $\begin{array}{l}\text { Yaş } \\
\text { (yıl) }\end{array}$ & $\begin{array}{c}\text { Değeri } \\
\text { (TL) }\end{array}$ & $\begin{array}{c}\text { Amortisman } \\
\text { (TL)* }\end{array}$ & $\begin{array}{c}\text { Yıllık Onarım } \\
\text { Bakım } \\
\text { Masrafı }\end{array}$ & $\begin{array}{c}\text { Toplam Sabit } \\
\text { Masraf }\end{array}$ & $\begin{array}{c}\text { Cari Dönem } \\
\text { Masraf }\end{array}$ \\
\hline $\mathrm{Ev}$ & 109,93 & 14,90 & 32594 & 1303,76 & 893,59 & 2197,35 & 721,21 \\
\hline Depo & 38,33 & 26,67 & 6667 & 266,67 & 0,00 & 266,67 & 0,00 \\
\hline Garaj & 15,50 & 9,00 & 10000 & 400,00 & 0,00 & 400,00 & 0,00 \\
\hline Ahir & 120,58 & 15,16 & 22471 & 898,84 & 932,08 & 1830,92 & 694,90 \\
\hline Samanlık & 84,85 & 21,19 & 11656 & 466,24 & 475,00 & 941,24 & 416,67 \\
\hline Toplam & 369,19 & & 83388 & 3 335,51 & 2300,67 & 5636,18 & 1832,78 \\
\hline \multicolumn{8}{|c|}{ PASİNLER } \\
\hline Bina nevi & $\begin{array}{c}\text { Alan } \\
\left(\mathbf{m}^{2}\right)\end{array}$ & $\begin{array}{l}\text { Yaş } \\
\text { (yıl) }\end{array}$ & $\begin{array}{c}\text { Değeri } \\
\text { (TL) }\end{array}$ & $\begin{array}{c}\text { Amortisman } \\
(\mathrm{TL})^{*}\end{array}$ & $\begin{array}{c}\text { Yıllık Onarım } \\
\text { Bakım } \\
\text { Masrafı } \\
\end{array}$ & $\begin{array}{c}\text { Toplam Sabit } \\
\text { Masraf }\end{array}$ & $\begin{array}{c}\text { Cari Dönem } \\
\text { Masraf }\end{array}$ \\
\hline $\mathrm{Ev}$ & 138,57 & 19,86 & 41429 & 1657,14 & 1196,15 & 2853,29 & 575,00 \\
\hline Depo & 62,50 & 9,67 & 15500 & 620,00 & 570,00 & 1190,00 & 340,00 \\
\hline Garaj & 35,00 & 6,00 & 6500 & 260,00 & 300,00 & 560,00 & 275,00 \\
\hline Ahır & 140,50 & 17,14 & 31429 & 1257,14 & 1448,15 & 2705,29 & 704,00 \\
\hline Samanlık & 167,78 & 13,67 & 16222 & 648,88 & 758,33 & 1407,21 & 591,67 \\
\hline Sulama Kanalı & 66,00 & 17,60 & 10000 & 400,00 & 1500,00 & 1900,00 & 750,00 \\
\hline Toplam & 610,35 & & 121079 & 4843,17 & 5772,63 & 10615,80 & ; 235,67 \\
\hline
\end{tabular}

\begin{tabular}{lrrrrrrr}
\hline \multirow{2}{*}{ Bina nevi } & \multicolumn{7}{c}{ ÇAT } \\
\cline { 2 - 8 } & $\begin{array}{c}\text { Alan } \\
\left(\mathbf{m}^{2}\right)\end{array}$ & \multicolumn{1}{c}{$\begin{array}{c}\text { Yaş } \\
(\mathbf{y ı l})\end{array}$} & $\begin{array}{c}\text { Değeri } \\
(\mathbf{T L})\end{array}$ & $\begin{array}{c}\text { Amortisman } \\
(\mathbf{T L}) *\end{array}$ & $\begin{array}{c}\text { Yıllık Onarım } \\
\text { Bakım Masrafı }\end{array}$ & $\begin{array}{c}\text { Toplam Sabit } \\
\text { Masraf }\end{array}$ & $\begin{array}{c}\text { Cari Dönem } \\
\text { Masraf }\end{array}$ \\
\hline Ev & 115,54 & 11,32 & 46250 & 1850,00 & 1447,37 & 3297,37 & 661,75 \\
Depo & 56,11 & 14,78 & 21778 & 871,11 & 625,00 & 1496,11 & 416,67 \\
Garaj & 33,33 & 9,00 & 5833 & 233,33 & 250,00 & 483,33 & 0,00 \\
Ahır & 131,96 & 9,00 & 31786 & 1271,43 & 1162,50 & 2433,93 & 587,50 \\
Samanlık & 74,00 & 10,25 & 16575 & 663,00 & 600,00 & 1263,00 & 375,00 \\
Sulama Kanalı & 100,00 & 30,00 & 15000 & 600,00 & 2000,00 & 2600,00 & 0,00 \\
\hline Toplam & $\mathbf{5 1 0 , 9 4}$ & & $\mathbf{1 3 7 2 2 2}$ & $\mathbf{5 4 8 8 , 8 7}$ & $\mathbf{6 ~ 0 8 4 , 8 7}$ & $\mathbf{1 1 ~ 5 7 3 , 7 4}$ & $\mathbf{2 ~ 0 4 0 , 9 2}$ \\
\hline
\end{tabular}

\begin{tabular}{lrrrrrrr}
\hline \multirow{2}{*}{ Bina nevi } & \multicolumn{7}{c}{ ERZURUM } \\
\cline { 2 - 8 } & $\begin{array}{c}\text { Alan } \\
\left(\mathbf{m}^{\mathbf{2}}\right)\end{array}$ & \multicolumn{1}{c}{$\begin{array}{c}\text { Yaş } \\
(\mathbf{y ı l})\end{array}$} & $\begin{array}{c}\text { Değeri } \\
(\mathbf{T L})\end{array}$ & $\begin{array}{c}\text { Amortisman } \\
(\mathbf{T L}) *\end{array}$ & $\begin{array}{c}\text { Yıllık Onarım } \\
\text { Bakım Masrafi }\end{array}$ & $\begin{array}{c}\text { Toplam Sabit } \\
\text { Masraf }\end{array}$ & $\begin{array}{c}\text { Cari Dönem } \\
\text { Masraf }\end{array}$ \\
\hline Ev & 122,26 & 14,40 & 39631 & 1585,23 & 1332,81 & 2918,03 & 700,43 \\
Depo & 39,24 & 12,78 & 10986 & 439,44 & 298,75 & 738,19 & 189,17 \\
Garaj & 30,02 & 9,50 & 7615 & 304,58 & 262,50 & 567,08 & 131,25 \\
Ahır & 152,34 & 13,25 & 29109 & 1164,35 & 1518,50 & 2682,85 & 871,60 \\
Samanlık & 109,24 & 14,34 & 14482 & 579,27 & 583,33 & 1162,60 & 345,84 \\
Sulama Kanalı & 54,00 & 14,40 & 9500 & 380,00 & 1250,00 & 1630,00 & 187,50 \\
\hline Toplam & $\mathbf{5 0 7 , 0 9}$ & & $\mathbf{1 1 1 ~ 3 2 2}$ & $\mathbf{4 ~ 4 5 2 , 8 8}$ & $\mathbf{5 2 4 5 , 8 9}$ & $\mathbf{9 6 9 8 , 7 6}$ & $\mathbf{2 4 2 5 , 7 8}$
\end{tabular}

*Amortisman \%4 alınmıştır. 
Çizelge 6. Makina varlığı, nevi, değeri ve masrafları ile alet ve ekipman masrafları (TL)

\begin{tabular}{|c|c|c|c|c|c|c|c|c|}
\hline \multirow[b]{2}{*}{ Makine nevi } & \multicolumn{7}{|c|}{ OLTU } & \multirow[b]{2}{*}{$\begin{array}{l}\text { Alet-ekipman } \\
\text { Masrafi (TL) }\end{array}$} \\
\hline & Adet & $\begin{array}{l}\text { Yas } \\
\text { (yIl) }\end{array}$ & $\begin{array}{l}\text { Değeri } \\
\text { (TL) }\end{array}$ & $\begin{array}{l}\text { Amortisman } \\
\text { (TL)* }\end{array}$ & $\begin{array}{c}\text { Onarım } \\
\text { Bakım Mas. }\end{array}$ & $\begin{array}{l}\text { Toplam Sabit } \\
\text { Masraf (TL) }\end{array}$ & $\begin{array}{l}\text { Cari Masraf } \\
\text { (TL) }\end{array}$ & \\
\hline Traktör & 1,00 & 7,79 & 28357 & 2835,71 & 2285,71 & 5121,42 & 12189,28 & \\
\hline Römork & 1,00 & 5,08 & 3846 & 384,62 & 300,00 & 684,62 & 500,00 & \\
\hline Ot biçme makin. & 1,00 & 1,00 & 1250 & 125,00 & 120,00 & 245,00 & 100,00 & \\
\hline Kazıyıcılar & 1,15 & 7,29 & 2143 & 214,29 & 800,00 & 1014,29 & 350,00 & \\
\hline Misır silaj makin. & 0,00 & 0,00 & 0,00 & 0,00 & 0,00 & 0,00 & 0,00 & \\
\hline Biçer-döver & 1,00 & 4,14 & 4357 & 435,71 & 850,00 & 1285,71 & 687,50 & \\
\hline Sağım makinası & 1,00 & 1,67 & 4403 & 440,30 & 250,00 & 690,30 & 50,00 & \\
\hline Toplam & & & 44356 & 3995,33 & 4605,71 & 8351,04 & 13876,78 & 3653,85 \\
\hline \multirow[b]{2}{*}{ Makine nevi } & \multicolumn{7}{|c|}{ NARMAN } & \\
\hline & Adet & $\begin{array}{l}\text { Yaş } \\
\text { (yIl) }\end{array}$ & $\begin{array}{c}\text { Değeri } \\
\text { (TL) }\end{array}$ & $\begin{array}{c}\text { Amortisman } \\
\text { (TL)* }\end{array}$ & $\begin{array}{c}\text { Onarım } \\
\text { Bakım Mas. }\end{array}$ & $\begin{array}{l}\text { Toplam Sabit } \\
\text { Masraf (TL) }\end{array}$ & $\begin{array}{c}\text { Cari Masraf } \\
\text { (TL) }\end{array}$ & $\begin{array}{l}\text { Alet-ekipman } \\
\text { Masrafi (TL) } \\
\end{array}$ \\
\hline Traktör & 1,00 & 5,80 & 35000 & 3500,00 & 1198,33 & 4698,33 & 8114,93 & \\
\hline Römork & 1,00 & 7,26 & 4694 & 469,43 & 100,00 & 569,43 & 0,00 & \\
\hline Ot biçme makin. & 1,00 & 4,67 & 15875 & 1587,50 & 200,00 & 1787,50 & 216,67 & \\
\hline Kazıyıcılar & 1,00 & 4,45 & 2818 & 281,82 & 116,67 & 398,49 & 125,00 & \\
\hline Misır silaj makin. & 1,00 & 1,00 & 32500 & 3250,00 & 0,00 & 3250,00 & 0,00 & \\
\hline Biçer-döver & 1,00 & 5,29 & 8286 & 828,59 & 670,00 & 1498,59 & 300,00 & \\
\hline Sağım makinası & 1,69 & 4,06 & 3469 & 346,88 & 83,33 & 430,21 & 50,00 & \\
\hline Toplam & & & 102642 & 9917,33 & 2368,33 & 12202,33 & 8806,60 & 3992,75 \\
\hline \multirow[b]{2}{*}{ Makine nevi } & \multicolumn{7}{|c|}{ PASINNLER } & \\
\hline & Adet & $\begin{array}{l}\text { Yaş } \\
\text { (yIl) }\end{array}$ & $\begin{array}{c}\text { Değeri } \\
\text { (TL) }\end{array}$ & $\begin{array}{c}\text { Amortisman } \\
\text { (TL)* }\end{array}$ & $\begin{array}{c}\text { Onarım } \\
\text { Bakım Mas. }\end{array}$ & $\begin{array}{l}\text { Toplam Sabit } \\
\text { Masraf (TL) }\end{array}$ & $\begin{array}{l}\text { Cari Masraf } \\
\text { (TL) }\end{array}$ & $\begin{array}{l}\text { Alet-ekipman } \\
\text { Masrafi (TL) }\end{array}$ \\
\hline Traktör & 1,06 & 8,33 & 31167 & 3116,67 & 1788,89 & 4905,56 & 9321,11 & \\
\hline Römork & 1,06 & 8,88 & 3938 & 393,75 & 341,67 & 735,42 & 100,00 & \\
\hline Ot biçme makin. & 1,25 & 9,75 & 6750 & 675,00 & 466,67 & 1141,67 & 175,00 & \\
\hline Kazıyıcılar & 1,60 & 10,50 & 2850 & 285,00 & 133,33 & 418,33 & 65,00 & \\
\hline Misir silaj makin. & 1,00 & 2,00 & 8500 & 850,00 & 450,00 & 1300,00 & 270,00 & \\
\hline Biçer-döver & 1,00 & 8,33 & 4411 & 441,11 & 587,50 & 1028,61 & 283,33 & \\
\hline Sağım makinası & 1,18 & 3,00 & 2932 & 293,18 & 557,14 & 850,32 & 125,00 & \\
\hline Toplam & & & 60574 & 5761,53 & 4325,20 & 9529,59 & 10339,44 & 4017,86 \\
\hline \multirow[b]{2}{*}{ Makine nevi } & \multicolumn{7}{|c|}{ ÇAT } & \\
\hline & Adet & $\begin{array}{l}\text { Yaş } \\
\text { (yIl) }\end{array}$ & $\begin{array}{l}\text { Değeri } \\
\text { (TL) }\end{array}$ & $\begin{array}{c}\text { Amortisman } \\
\text { (TL)* }\end{array}$ & $\begin{array}{c}\text { Onarım } \\
\text { Bakım Mas. }\end{array}$ & $\begin{array}{l}\text { Toplam Sabit } \\
\text { Masraf (TL) }\end{array}$ & $\begin{array}{c}\text { Cari Masraf } \\
\text { (TL) }\end{array}$ & $\begin{array}{l}\text { Alet-ekipman } \\
\text { Masrafi (TL) }\end{array}$ \\
\hline Traktör & 1,00 & 8,23 & 33769 & 3376,92 & 1546,15 & 4923,07 & 6835,67 & \\
\hline Römork & 1,00 & 10,23 & 4769 & 476,92 & 0,00 & 476,92 & 0,00 & \\
\hline Ot biçme makin. & 1,00 & 10,00 & 2500 & 250,00 & 0,00 & 250,00 & 0,00 & \\
\hline Kazıyıcılar & 1,20 & 8,40 & 3100 & 310,00 & 416,67 & 726,67 & 250,00 & \\
\hline Misır silaj makin. & 1,00 & 5,00 & 2333 & 233,33 & 250,00 & 483,33 & 500,00 & \\
\hline Biçer-döver & 1,00 & 3,29 & 5429 & 542,86 & 255,00 & 797,86 & 316,67 & \\
\hline Sağım makinası & 1,27 & 3,33 & 2020 & 202,03 & 278,46 & 480,49 & 263,64 & \\
\hline Toplam & & & 53912 & 5190,04 & 2746,28 & 7657,86 & 8165,98 & 2875,00 \\
\hline \multirow[b]{2}{*}{ Makine nevi } & \multicolumn{7}{|c|}{ ERZURUM } & \\
\hline & Adet & $\begin{array}{l}\text { Yaş } \\
\text { (yIl) }\end{array}$ & $\begin{array}{l}\text { Değeri } \\
\text { (TL) }\end{array}$ & $\begin{array}{c}\text { Amortisman } \\
\text { (TL)* }\end{array}$ & $\begin{array}{c}\text { Onarım } \\
\text { Bakım Mas. }\end{array}$ & $\begin{array}{l}\text { Toplam Sabit } \\
\text { Masraf (TL) }\end{array}$ & $\begin{array}{c}\text { Cari Masraf } \\
\text { (TL) }\end{array}$ & $\begin{array}{l}\text { Alet-ekipman } \\
\text { Masrafi (TL) }\end{array}$ \\
\hline Traktör & 1,02 & $\frac{1}{7,54}$ & 32073 & 3207,33 & 1704,77 & 4912,10 & 9115,25 & \\
\hline Römork & 1,02 & 7,86 & 4312 & 431,18 & 185,42 & 616,60 & 150,00 & \\
\hline Ot biçme makin. & 1,06 & 6,36 & 6594 & 659,38 & 196,67 & 856,04 & 122,92 & \\
\hline Kazıyıcılar & 1,24 & 7,66 & 2728 & 272,78 & 366,68 & 639,44 & 197,50 & \\
\hline Misır silaj makin. & 0,75 & 2,00 & 10833 & 1083,33 & 175,00 & 1258,33 & 192,50 & \\
\hline Biçer-döver & 1,00 & 5,26 & 5621 & 562,07 & 590,63 & 1152,69 & 396,88 & \\
\hline Sağım makinası & 1,29 & 3,02 & 3206 & 320,60 & 292,23 & 612,83 & 122,16 & \\
\hline Toplam & & & 65367 & 6216,06 & 3511,40 & 9435,20 & 10175,03 & 3634,87 \\
\hline
\end{tabular}




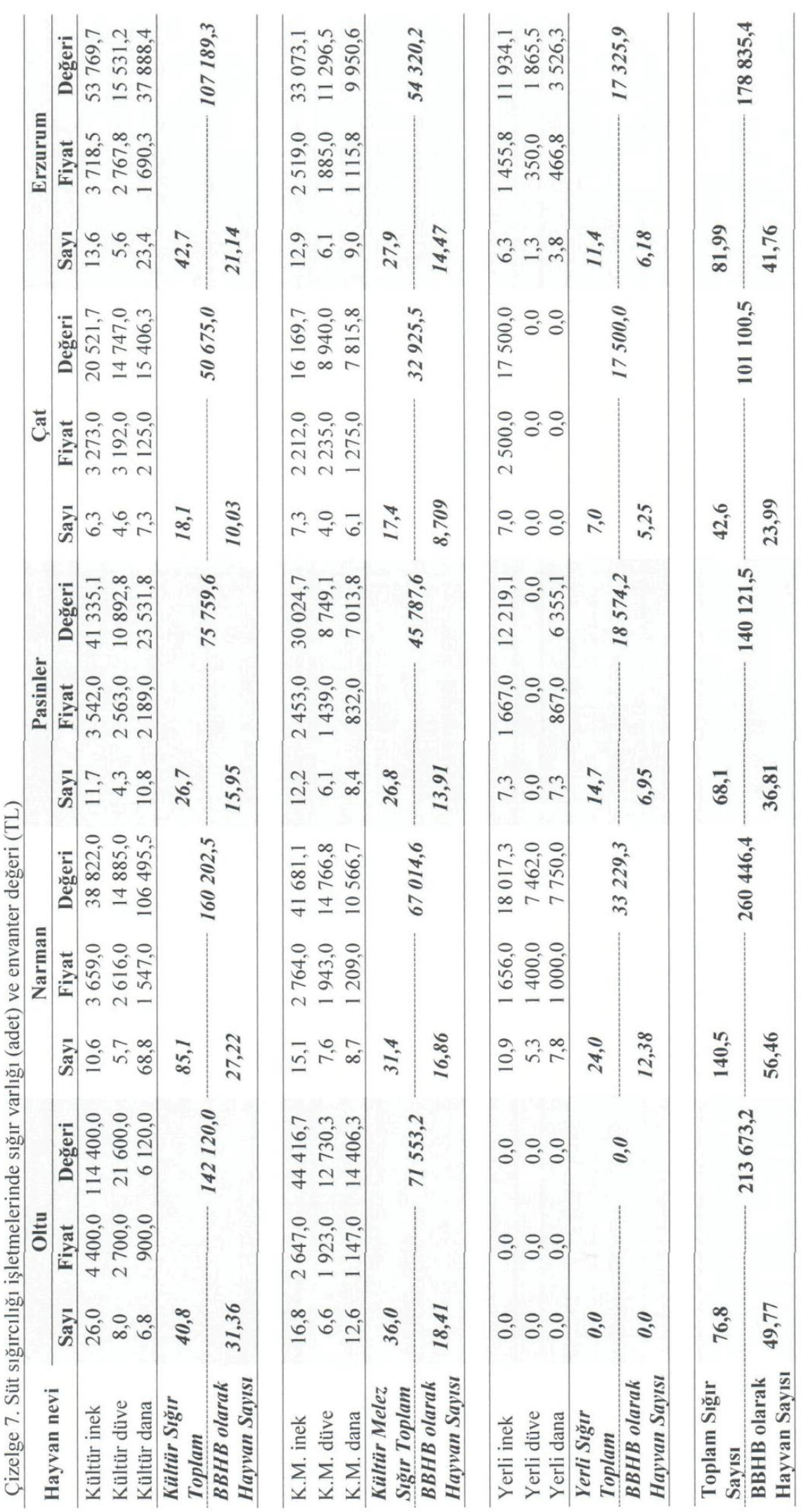




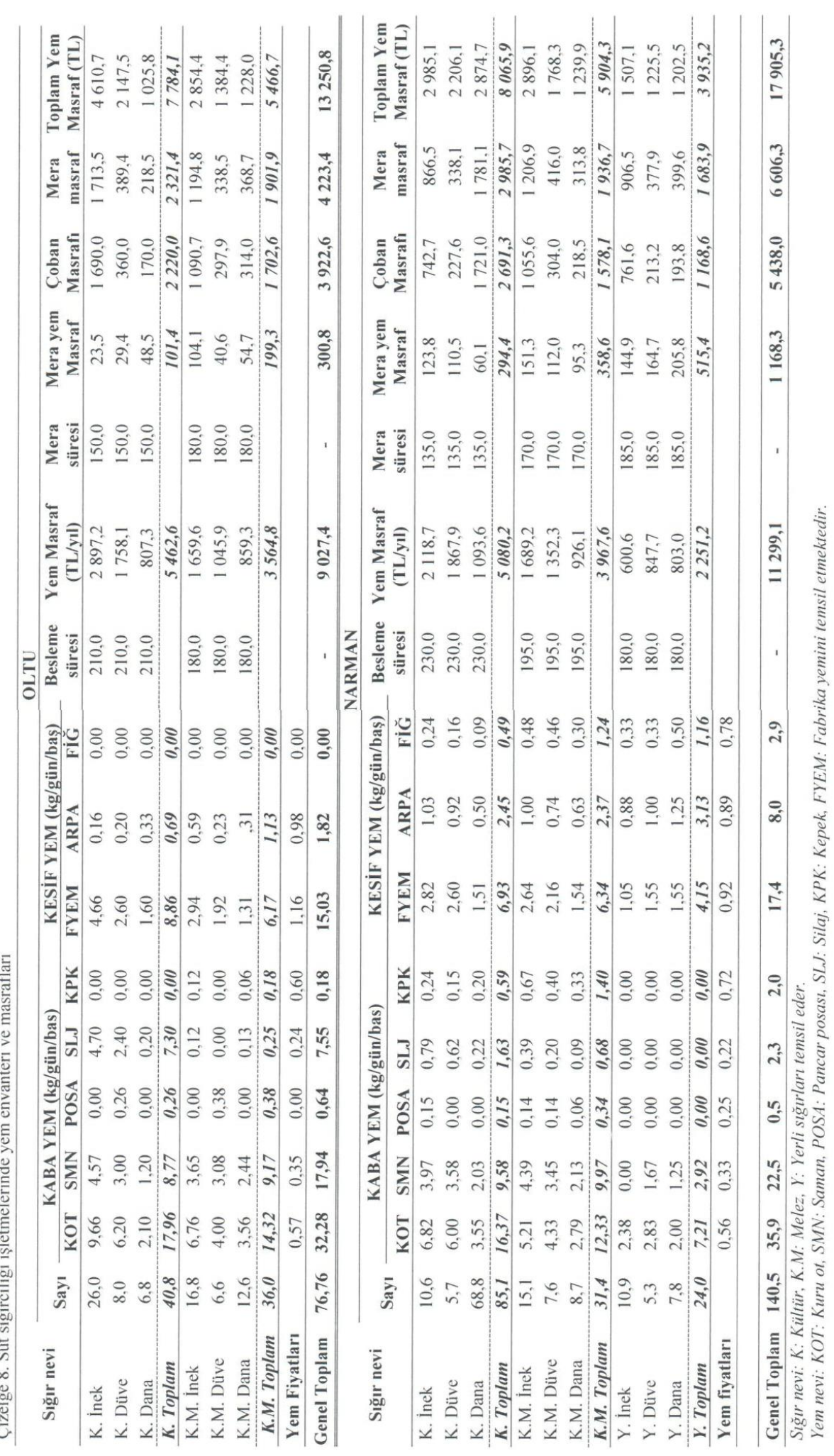




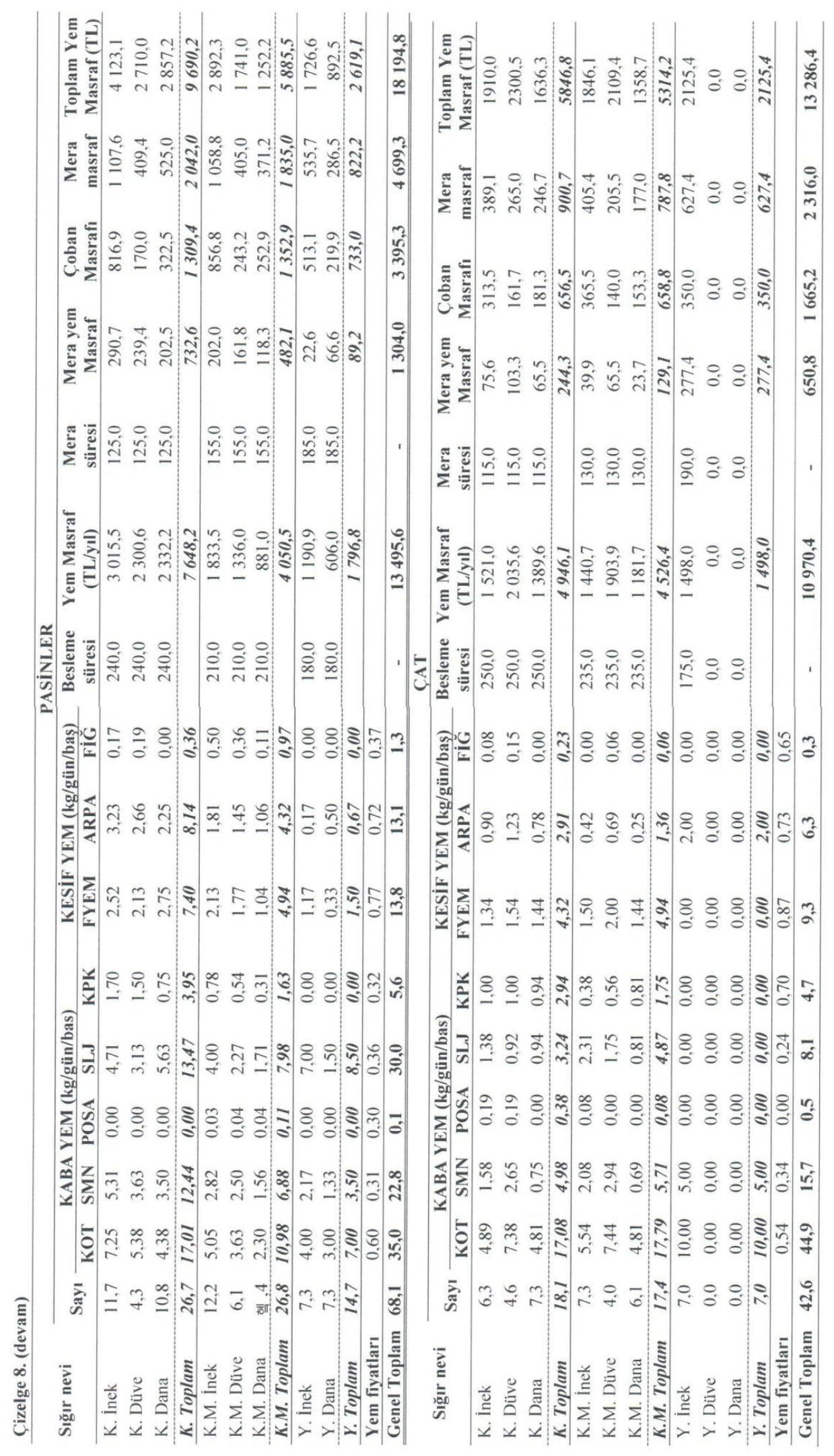




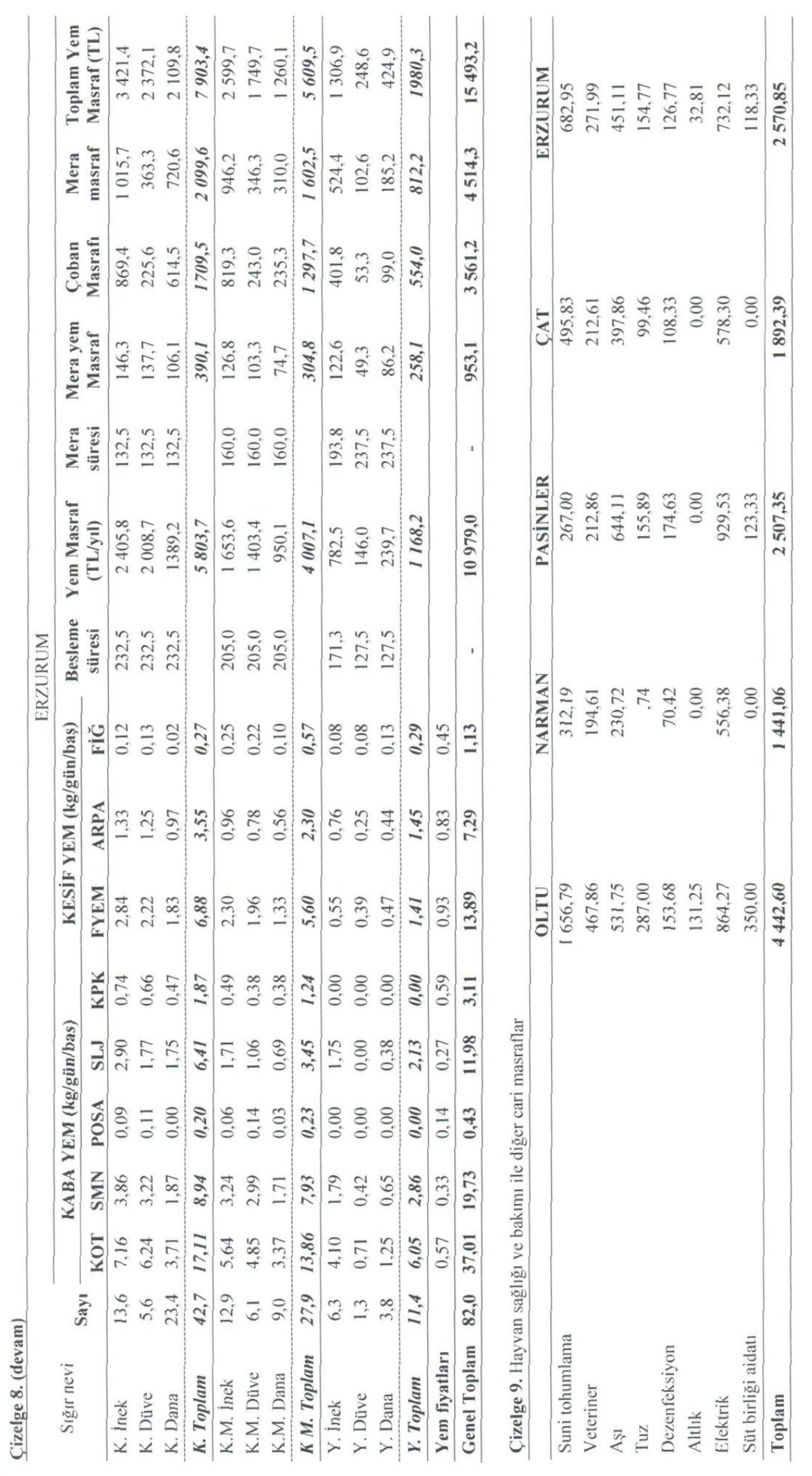


Çizelge 9. Hayvan sağlı̆̆ ve bakımı ile diğer cari masraflar

\begin{tabular}{|c|c|c|c|c|c|}
\hline & OLTU & NARMAN & PASÍNLER & ÇAT & ERZURUM \\
\hline Suni tohumlama & 1656,79 & 312,19 & 267,00 & 495,83 & 682,95 \\
\hline Veteriner & 467,86 & 194,61 & 212,86 & 212,61 & 271,99 \\
\hline Aş1 & 531,75 & 230,72 & 644,11 & 397,86 & 451,11 \\
\hline Tuz & 287,00 & 76,74 & 155,89 & 99,46 & 154,77 \\
\hline Dezenfeksiyon & 153,68 & 70,42 & 174,63 & 108,33 & 126,77 \\
\hline Altlik & 131,25 & 0,00 & 0,00 & 0,00 & 32,81 \\
\hline Elektrik & 864,27 & 556,38 & 929,53 & 578,30 & 732,12 \\
\hline Süt birliği aidatı & 350,00 & 0,00 & 123,33 & 0,00 & 118,33 \\
\hline Toplam & 4442,60 & 1441,06 & 2507,35 & 1892,39 & 2570,85 \\
\hline
\end{tabular}

\subsection{Süt sığırcılığı işletmelerinde bilanço analizi}

Süt sığırcılığı işletmelerinde bilanço analizi

Süt sığırcılığ işletmesinin özetlenmiş ortalama aktif ve pasif değerleri ifade eden 2013-2014 cari dönem sonu bilançosu, Çizelge 10'da verilmiştir. Yarı entansif süt sığırcılığı işletmelerinde duran varlıkların toplam aktifler içerisindeki payları Oltu, Narman, Pasinler ve Çat ilçeleri ile Erzurum ortalamasına göre sirasıyla $\% 85, \% 83, \% 81, \% 82$ ve $\% 87$ olarak hesaplanmıştır. Benzer şekilde pasifler içerisinde öz kaynaklar \%72, \%78, \%77, \%80 ve $\% 83$ iken, toplam yabancı kaynaklar içerisinde kısa vadeli borçlar ise $\% 62, \% 87, \% 84, \% 84$ ve $\% 80$ pay almaktadır (Çizelge 10). İşletmelerin dönen aktifler değerleri oldukça düşük düzeylerde olup; cari işletme varlıklarını karşılayarak üretime devam edebilmeleri ve üçüncü şahıslara karşı finansal sorumluluklarını yerine getirebilmek için yoğun bir şekilde kısa vadeli borçlanmaya gitmişlerdir. $\mathrm{Bu}$ durum işletmelerin malzeme ve mühimmat varlığı ile özellikle de likid varlıkların yetersiz olduğunu göstermektedir.

Çizelge 10. Süt sığırcılığı işletmelerinin 2013-2014 cari dönem sonu özet bilançosu

\begin{tabular}{|c|c|c|c|c|c|}
\hline & OLTU & NARMAN & PASINLER & ÇAT & ERZURUM \\
\hline 1. Dönen aktifler & 151232 & 165161 & 213895 & 179909 & 203999 \\
\hline 1.1. Kasa varlığı & 10000 & 6250 & 13333 & 17500 & 11771 \\
\hline 1.2. Kısa vadeli alacaklar & 75855 & 61729 & 38900 & 78500 & 63746 \\
\hline 1.3. Malzeme ve mühimmat varlı̆̆ı & 65377 & 97181 & 161661 & 83909 & 128483 \\
\hline 2. Duran aktifler & 874849 & 819917 & 892091 & 791754 & 1314081 \\
\hline 2.1. Alacaklar toplami & 65000 & 0 & 5000 & 18000 & 59500 \\
\hline 2.2. Nebat varlı̆̆l & 12388 & 106756 & 5356 & 47986 & 51815 \\
\hline 2.3. Net maddi duran varlıklar & 797462 & 713161 & 881736 & 725768 & 1202766 \\
\hline I. Aktifler Toplamı & 1026081 & 985078 & 1105986 & 971663 & 1518080 \\
\hline 1. Yabancı kaynaklar & 288304 & 219041 & 250861 & 194246 & 263300 \\
\hline 1.1. Kisa vadeli borclar & 178137 & 190674 & 210305 & 163496 & 210840 \\
\hline 1.1.1. Banka borcu & 8650 & 12147 & 12345 & 16445 & 12397 \\
\hline 1.1.2. Ticari borçlar (materyal alımı) & 30706 & 48699 & 47519 & 31410 & 48287 \\
\hline 1.1.3. İşçilik borçları & 29603 & 26061 & 33843 & 21529 & 25322 \\
\hline 1.1.4. Diğer cari borçlar & 60310 & 74760 & 81362 & 52940 & 73610 \\
\hline 1.1.5. Kira borçlart & 12716 & 8155 & 16735 & 17002 & 25948 \\
\hline 1.1.6. Uzun vadeli borç karşılıklart & 34842 & 12885 & 16146 & 22688 & 21872 \\
\hline 1.1.7. Hayvan envanter klymet azalışı & 1310 & 7967 & 2355 & 1482 & 3405 \\
\hline 1.2. Uzun vadeli borçlar & 110167 & 28367 & 40556 & 30750 & 52460 \\
\hline 1.3. Orta vadeli borçlar & 29200 & 19500 & 20800 & 60000 & 32375 \\
\hline 2. Öz kaynaklar & 737777 & 766037 & 855125 & 777417 & 1254780 \\
\hline 2.1. Oz sermaye & 657861 & 420205 & 678365 & 637612 & 1076077 \\
\hline 2.2. Hayvan envanter kıymet artışı & 40063 & 138605 & 42181 & 31992 & 62649 \\
\hline 2.3. Amortismanlar & 73647 & 97715 & 81106 & 87850 & 92852 \\
\hline 2.4. Dönem net karı (VÖNK) & -33794 & 109512 & 53473 & 19963 & 23202 \\
\hline II. Pasifler Toplamı & 1026081 & 985078 & 1105986 & 971663 & 1518080 \\
\hline
\end{tabular}


Süt sı̆̆ırcılığı işletmelerinin dönem sonu faaliyet gelir ve gider analizi

Süt sığırcılığı işletmesinin 2013-2014 üretim yılına ait ortalama dönem sonu faaliyet gelirleri ile üretim masrafları, Çizelge 11 'de verilmiştir. Faaliyet gelirleri bakımından en yüksek paya sahip olan işletmelerin Narman İlçesinde yoğunlaştığ düşük sabit masraflara karşılık daha yüksek değişken masraflar ile faaliyetlerini sürdürmektedir. $\mathrm{Bu}$ yüzden en yüksek faiz ve vergi öncesi kar (FAVÖK) ile vergi öncesi kara (VÖK) sahip işletmeler, bu ilçede yoğunlaşmıştır. Bu ilçeyi maliyet etkinliği yönünden Pasinler İlçesi ve Erzurum takip ederken, Oltu İlçesi maliyet etkinliğinde en kötü durumda olan işletmelere sahiptir.

Çizelge 11. Süt sığırcılığı işletmelerinin 2013-2014 dönem sonu faaliyet gelir ve gider tablosu

\section{FAALIYYT GELIRLERI}

\begin{tabular}{|c|c|c|c|c|c|}
\hline & OLTU & NARMAN & PASİNLER & ÇAT & ERZURUM \\
\hline 1. Toplam faaliyet gelirleri (TR) & 168003 & 297789 & 244984 & 209471 & 258719 \\
\hline 1.1. Yem bitkileri üretim geliri & 59878 & 95331 & 159161 & 82059 & 125557 \\
\hline 1.2. Ham süt geliri & 48155 & 49854 & 26314 & 60057 & 48874 \\
\hline 1.3. Süt ürünleri geliri & 11157 & 9899 & 10192 & 29846 & 15263 \\
\hline 1.4. Damızlık envanter kıymet artışı & 40063 & 138605 & 42181 & 31992 & 62649 \\
\hline 1.5. Diğer tarımsal faaliyet gelirleri & 8750 & 4100 & 7136 & 5517 & 6376 \\
\hline 2. Toplam faaliyet masrafları $(T C)$ & 166955 & 175392 & 175365 & 166820 & 213645 \\
\hline 2.1. Toplam sabit masraflar (TFC) & 94508 & 83380 & 91497 & 80889 & 104500 \\
\hline 2.1.1. Kira masraflart & 16836 & 13385 & 18299 & 27086 & 37260 \\
\hline 2.1.1.1. Yem bitkileri için kira masrafı & 12716 & 8155 & 16735 & 17002 & 25948 \\
\hline $\begin{array}{l}\text { 2.1.1.2. Nebat ve tarla demirbaş için kira } \\
\text { masrafi }\end{array}$ & 4120 & 5230 & 1564 & 10084 & 11312 \\
\hline 2.1.2. Bina ve tarımsal yapı masrafları & 10969 & 5636 & 10616 & 11262 & 9699 \\
\hline 2.1.2.1. Amortisman masrafları & 4144 & 3336 & 4843 & 5489 & 4453 \\
\hline 2.1.2.2. Y1llık onarım-bakım masrafları & 6825 & 2301 & 5773 & 5773 & 5246 \\
\hline 2.1.3. Alet ve makine masraflart & 8601 & 12286 & 10087 & 7936 & 9727 \\
\hline 2.1.3.1. Amortisman masrafları & 3995 & 9917 & 5762 & 5190 & 6216 \\
\hline 2.1.3.2. Y1llık onarım-bakım masrafları & 4606 & 2368 & 4325 & 2746 & 3511 \\
\hline 2.1.4. Süt slğır materyal masrafları & 23998 & 22041 & 14295 & 9224 & 17516 \\
\hline 2.1.4.1. Amortisman & 22688 & 14074 & 11940 & 7742 & 14111 \\
\hline 2.1.4.2. Envanter kıymet azalışı & 1310 & 7967 & 2355 & 1482 & 3405 \\
\hline 2.1.5. Daimi aile işgücü masraflart & 29603 & 26061 & 33843 & 21529 & 25322 \\
\hline Sabit Masraflar Toplamı (A) & 90008 & 79409 & 87140 & 77037 & 99524 \\
\hline 2.1.6. Sabit serm. Fursat maliyeti $(A * \% 5)$ & 4500 & 3971 & 4357 & 3852 & 4976 \\
\hline 2.2. Toplam değişir masraflar (TVC) & 72447 & 92012 & 83868 & 85931 & 109145 \\
\hline 2.2.1. Bitkisel üretim materyal masrafları & 22343 & 48799 & 33480 & 45110 & 61656 \\
\hline 2.2.1.1. Yem bitkileri materyal masrafları & 17455 & 30793 & 29324 & 18124 & 33076 \\
\hline $\begin{array}{l}\text { 2.2.1.2. Nebat ve tarla demirbaşı materyal } \\
\text { masraf. }\end{array}$ & 4888 & 18006 & 4156 & 26986 & 28580 \\
\hline 2.2.3. Yem masraflart & 13251 & 17905 & 18195 & 13286 & 15211 \\
\hline 2.2.4. Hayvan sağhlı̆̆ ve diğer masraflar & 4443 & 1441 & 2507 & 1892 & 2571 \\
\hline 2.2.5. Bina cari dönem işletme masrafları & 9419 & 4133 & 9008 & 8126 & 7672 \\
\hline 2.2.6. Makine cari dönem işletme masraflart & 13877 & 8807 & 10339 & 8166 & 10175 \\
\hline 2.2.7. Alet ve ekipman masraflart & 3654 & 3993 & 4018 & 2875 & 3635 \\
\hline Değişir Masraflar Toplamı (B) & 68997 & 87630 & 79873 & 81839 & 103948 \\
\hline 2.2.8. Genel idare masraflart $(B * \% 3)$ & 2010 & 2552 & 2326 & 2384 & 3028 \\
\hline 2.2.9. Değişir serm. firsat maliyeti $(B * \% 5)$ & 3450 & 4382 & 3994 & 4092 & 5197 \\
\hline 3. Faiz ve vergi öncesi kar (FAVÖK) & 1048 & 122397 & 69619 & 42651 & 45074 \\
\hline Cari dönem faiz ve ana kapital ödemeleri (-) & 34842 & 12885 & 16146 & 22688 & 21872 \\
\hline 4. Vergi öncesi net kar (VÖK) & -33794 & 109512 & 53473 & 19963 & 23202 \\
\hline
\end{tabular}


Süt sığırcılığı işletmelerinin dönem sonu faaliyet ve karlılık oranları

Yarı entansif süt sı̆̆ırcılığı işletmelerinde cari dönem faaliyet sonuçlarına göre analiz edilen faaliyet ve karlılık oranları, Çizelge 12'de verilmiştir. Süt sığırcılı̆̆ı işletmelerinde faaliyet sonu başarı durumunu ifade eden faaliyet oranı (AT), Narman ve Pasinler İlçelerinde daha yüksektir. Oltu ilçesinde ise en düşük düzeyde olup, hemen hemen normal kar eşiğindedir. Dolayısıyla işletmelerinin karlı bir faaliyet sürdürebilmeleri için $A T$ 'nin 1 'den daha büyük olması gerekir (Bolak, 2008; Çetin, 2008; Er, 2009; Topcu, 2018). Çünkü tarım işletmelerinin karlı bir üretim faaliyeti sürdürebilmeleri için toplam üretim değerlerinin toplam masraflarından daha büyük olması gerekmektedir. AT'nin düşük olmasının nedenleri; işletmelerin net duran aktiflerinin toplam sermaye içerisinde yüksek oranlarda olmasından dolayı, kıt kaynaklarda teknik etkinliğin sağlanamayarak maliyet etkinsizliği ya da ölçek ekonomilerinin optimal düzeyde kullanılamaması ile toplam üretim değerinin düşük olmasıdır.

Diğer taraftan sermaye $(C T)$ ve öz sermaye devir oranları $(E T)$, bütün ilçelerde çok düşük düzeylerde olup tarım işletmelerinde olduğu gibi bu faaliyet birimi de aktifler ile öz sermaye karşıllı̆gında üretimden sağladıkları faydalar bakımından büyük bir risk ile karşı karşıyadır (Çizelge 12). Narman ilçesi öz sermaye etkinliğini en iyi kullanan işletmelere sahipken, aktifler yönünden diğer ilçe işletmeleri ile benzer riskler göstermektedir. $\mathrm{Bu}$ durum daha çok işletmelerin sabit varlılara yoğun yatırım yapmaları ve mevcut kapasitenin altında üretim faaliyetini gerçekleşmelerinden kaynaklanan kar marjlarının düşük düzeylerde seyretmesine neden olmaktadır.

Aktif varlıklar içerisinde dönen ve net duran varlıkların üretim değerine dönüşme oranlarını ifade eden dönen aktif $(C A T)$ ve net maddi duran varlık (TFAT) devir oranları, aktif varlıkların üretim değerine dönüşümleri hakkında daha ayrıntılı bilgi sunmaktadır. CAT, Narman ilçesinde en yüksek orana sahipken, Oltu ilçesinde en düşük düzeydedir. İşletmelerde dönen aktiflerin üretim değeri üzerindeki etkinliği yönünden risk düşük, fakat cari varlıkların temin edilmesi için kısa vadeli borç edinimleri yüksek risk faktörüdür. Nitekim net işletme sermayesi devir oranı (NWCT), Pasinler ve Çat ilçeleri dışında ilçe işletmelerinde büyük bir risk kaynağıdır. TFAT, Narman ilçesinde iyi durumda, fakat diğer ilçelerde daha düşük katkı sunmaktadır. Özellikle aktif değerlerde olduğu gibi bütün ilçelerde net maddi duran varlıkların üretim değerine katkısı oldukça düşük ve gerekçesi ise bu varlıkların üretime katılımı optimal ölçeğin altında teşekkül etmektedir. NWCT bakımından Pasinler ilçesi çok iyi bir durumda iken, Çat ilkesi de kendi dönen aktifler ile faaliyetlerini sürdürebilecek durumdadır. Özellikle Pasinler ilçesi işletmeleri malzeme ve mühimmat varlığı yönünden süt sığırcılığı faaliyetlerinde yüksek bir etkinliğe sahiptir.

Çizelge 12. Süt sığırcılığ

\begin{tabular}{|c|c|c|c|c|c|}
\hline & OLTU & NARMAN & PASINLER & ÇAT & ERZURUM \\
\hline \multicolumn{6}{|c|}{ Süit sığırcılığı işletmelerinin dönem sonu faaliyet oranları } \\
\hline Faaliyet oranı $(A T)$ & 1,01 & 1,70 & 1,40 & 1,26 & 1,21 \\
\hline Sermaye devir oranı $(C T)$ & 0,16 & $\mathbf{0 , 3 0}$ & 0,22 & 0,22 & 0,17 \\
\hline Öz sermaye devir oranı (ET) & 0,26 & 0,71 & 0,36 & 0,33 & 0,24 \\
\hline Net işletme sermayesi devir oranı & & & & & \\
\hline$(N W C T)$ & $-6,24$ & $-11,67$ & 68,24 & 12,76 & $-37,82$ \\
\hline Dönen aktif devir oranı (CAT) & 1,11 & $\mathbf{1 , 8 0}$ & 1,15 & 1,16 & 1,27 \\
\hline $\begin{array}{l}\text { Net maddi duran aktif devir oranı } \\
\text { (TFAT) }\end{array}$ & 0,21 & $\mathbf{0 , 4 2}$ & 0,28 & 0,29 & 0,22 \\
\hline \multicolumn{6}{|c|}{ Süt sığırcılığı işletmelerinin dönem sonu karlılık oranları } \\
\hline Brüt $\operatorname{Kar}(G P)$ & 95556 & 205777 & 161116 & 123540 & 149574 \\
\hline Brüt kar marjı (GPM) (\%) & 56,88 & 69,10 & 65,77 & 58,98 & 57,81 \\
\hline Net kar marjı (NPM) (\%) & $-20,12$ & 36,78 & 21,83 & 9,53 & 8,97 \\
\hline Devamll sermaye karlılı̆̆ (ROLTS) (\%) & $-4,40$ & 24,41 & 7,44 & 2,99 & 2,06 \\
\hline Mali rantabilite $(F P)(\%)$ & $-5,14$ & 26,06 & 7,88 & 3,13 & 2,16 \\
\hline Ekonomik rantabilite (EP) (\%) & 0,10 & 12,43 & 6,29 & 4,39 & 2,97 \\
\hline
\end{tabular}

Süt sığırcılığı işletmelerinin faaliyet sonu başarı oranları hakkında önemli bilgi veren karlılık oranları dikkate alınırsa; brüt kar marjı $(G P M)$ ve net kar marjı (NPM), Narman ve Pasinler ilçelerinde çok daha iyi faaliyet sonu net getirisi sağlamaktadır. Ancak devamlı sermaye karlılığını (ROLTS), Narman 
ilçesi dışındaki diğer ilçe işletmeleri mevcut sermayenin maliyeti altındaki karlara maruz kalmaktadır. Yine mali $(F P)$ ve ekonomik rantabilite $(E P)$ analiz sonuçları da Narman ilçesi işletmelerinin cari dönem firsat maliyetine karşılık verebilecek bir kar oranına sahipken, diğer ilçeler aktif sermayelerinin cari dönem faiz karşılıklarının dahi altında bir kar marjı ile faaliyetlerine dezavantajlı olarak devam etmektedirler.

\section{SONUÇ VE ÖNERİLER}

Erzurum ilindeki yarı entansif süt sığırcılığı işletmelerinin bilanço ve gelir analiz sonuçları; toplam aktifler içerisinde sabit varlıkların payı \%87 ve aktiflerin \%83'ünün öz kaynaklardan sağlandığını, fakat yabancı kaynakların \%80'nin kısa vadeli borçlardan teşekkül ettiğini göstermiştir. Bu durum, işletmelerin dönen aktiflerinin büyük bir bölümünün kısa vadeli borçlarla karşılanarak cari faaliyet döneminde borç yüklerinin yüksek olduğu ve karlılığı önemli ölçüde düşürdüğü anlamına gelmektedir.

Aynı zamanda araştırma sonuçları, süt sı ğırcılı̆̆ 1 işletmelerinde faaliyet oranlarının Narman ve Pasinler ilçelerinde faaliyetlerin sürdürülebilirliği açısından daha düşük ekonomik risklerle karşı karşıya olunduğu, fakat sermaye devir oranının çok düşük olmasından dolayı potansiyel bir riske de işaret etmektedir. Ancak diğer ilçe işletmeleri faaliyet ve sermaye devir oranları arasındaki etkileşimin bir sonucu olarak, çok daha büyük risklerle karşı karşıyadır. Özellikle cari dönem başarısının en önemli kriterlerinden net işletme sermayesi devir oranı, Pasinler ve Çat ilçeleri işletmelerinde iyi durumda iken; diğer işletmeler çok daha büyük bir risk üstlenmiş durumdadır. Dolayısıyla cari dönem malzeme ve mühimmat varlığı ile likid değerler, bu ilçelerin dışında büyük bir oranda kısa vadeli borçlarla sürdürülmektedir. Bu yüzden süt sığırcılığg işletmelerinde net işletme sermayesi, aktif varlıklar aleyhine olmak üzere artırılmalı ve yatırım planlamalarında sabit varlıklar optimal ölçeklere çekilerek, atıl olabilecek kapasite karşılıkları cari varlıkların temininde kullanılmalıdır.

Süt sığırcılığg işletmelerinin faaliyet sonu karlılık oranları ile ilgili araştırma sonuçları da, Narman ilçesinin mutlak bir üstünlüğe sahip olduğu ve faaliyet sonu başarısının diğer ilçelerden çok yüksek olduğuna işaret etmektedir. Net kar marj1 yönünden Narman ve Pasinler ilçeleri \%37 ve \%22'lik marjlarına sahip olarak, iç karlık oranlarını yüksek seviyelere taşımalarına rağmen, mali ve ekonomik rantabilite bakımından Pasinler ilçesi dezavantajlı duruma düşmektedir. Pasinler ilçesi işletmelerinin toplam üretim değeri içerisinde net kar oranı kabul edilebilir durumda olmasına rağmen, aktif ve öz sermaye karşılığında elde edilen FAVÖK ile $V O ̈ N K$ bakımında rekabet edebilir ve sürdürülebilir bir faaliyet karı sağlayamamaktadırlar. Dolayısıyla Narman ilçesi dişındaki diğer ilçe işletmeleri öz sermaye artırımı ile aktif değerlerinde artış sağlayarak, orta ve uzun vadede süt sığırcılığı faaliyetini karlı ve sürdürülebilir kılabilirler.

\section{TEŞEKKÜR}

BAP-2012/421 nolu araştırma projesinden türetilen mevcut çalışmayı, finansal olarak destekleyen Atatürk Üniversitesi Bilimsel Araştırma Projeleri Fonu'na teşekkür ederim.

\section{KAYNAKLAR}

Anonim, 2013. Erzurum İl G1da, Tarım ve Hayvancılık Müdürlüğü Kayıtları, Erzurum.

Anonim, 2017. Erzurum İl Gida, Tarım ve Hayvancilık Müdürlüğü Hayvan ve Hayvansal Ürünler Kayıtları, Erzurum.

Aral, S., 1989. İktisadi kalkınmamızda hayvansal üretim politikasının yeri ve önemi. Vet. Hek. Der. Derg., (3-4): 19-24.

Aşkan, E., Dağdemir, V., 2016. TRA1 Düzey 2 destek ve teşvik alan süt sığırcılığı işletmelerinde sür üretim maliyeti ve karlılık durumu. TEAD, 2 (1): 1-12.

Aşkan, E., Dağdemir, V., 2015. Devlet desteklemelerinden faydalanan süt sığırcılığ1 işletmelerinin üretim değerini etkileyen faktörlerin analizi: Erzurum, Erzincan ve Bayburt illerinin örneği. Tarım Ekon. Derg., 21 (2): 69-76.

Aydın, R., Güler, O., Yanar, M., Diler, A., Koçyiğit, R., Avc1, M., 2016. Erzurum ili Hınıs ilçesi sığırcılık işletmelerinin barınak özellikleri üzerine bir araştırma. KSÜ Doğa Bil. Derg., 19(1): 37-42.

Bolak, M., 2008. İşletme Finansı. Birsen Yayınevi, 2. Basım, İstanbul.

Çelik, Y., Bayramoğlu, Z., Gündüz, O. Karakayacı, Z., 2016. Konya İlinde farklı işletme tiplerinin yıllık faaliyet sonuçları ve karlı işletme tiplerinin tespiti. Türk Tarım ve Doğa Bilim. Derg., 3(2): 161-171.

Çetin, B., 2008. Tarımsal Finansman. Nobel Yayın Dağıtım, Ankara.

Direk, M., Bayramoğlu, Z., 2007. Konya İlinde tarımsal kalkınma kooperatiflerinin ortaklığı olan süt sığırcılığı işletmelerinin ekonomik faaliyet sonuçları. Selçuk Üniv. Ziraat Fak. Derg., 21(41): 1-10. 
Er, E., 2009. Basel-II Kriterlerini anlama yolunda mali tablolar ve finansal analizin önemi. Bursa Bilanço, 113(11): 52-60.

FAOSTAT, 2017. Download and visualize data of livestock processed and primary product production. http://www.fao.org/faostat/ (Erişim Tarihi: 27 Şubat 2017).

Hazneci, E., Ceyhan, V., 2011. Amasya ili Merzifon ilçesinde süt sığırcılığı yapan tarım işletmelerinde risk analizi. Anadolu J. AARI, 18(1): 66-92.

Ilgaz, B., 2017. Oran Analizleri. http://www.bilgaz.net/ (Erişim Tarihi: 10 Mart 2017).

İnan, İ.H., 2001. Tarım Ekonomisi ve İşletmeciliği. Avc1 Ofset, İstanbul, ISBN: 975-93281-0-0.

Kıral, T., Kasnakoğlu, H., TAtlıdil, F., Fidan, H., Gündoğmuş, E., 1999. Tarımsal Ürünler için Maliyet Hesaplama Metodolojisi ve Veri Tabanı Rehberi. TEAE, Aralık 1999, Ankara.

Kızılay, H., Akçaöz, H., 2008. Antalya ilinde süt sığırı yetiştiricileri birliğine üye olan ve olmayan işletmelerde risk analizi. Akdeniz Üniv. Ziraat Fak. Derg., 24(2): 109-114.

Koçyiğit, R., Aydın, R., Diler, A., Güler, O., Yanar, M., 2016. Erzurum ili Hınıs ilçesindeki sığırcılık işletmelerinin yapısal özellikleri: sağım yönetimi. Harran Tarım ve G1da Bilimleri Derg., 20(4): 322-329.

Köseoğlu, M., 2017. Finansal Rapor Oran Analizleri. TUMSİAD. http://www.muratkoseoglu.com.tr/ (Erişim Tarihi: 20 Mart 2017).

Selvi, M.H., Yanar, M., 2016. Esmer sığırlarda süt verimine etkili çevre faktörleri ile fenotipik, genetik ve çevresel yönelimler ve bazı genetik parametrelerin belirlenmesi. Türk Tarım-Gıda Bilim ve Teknoloji Derg., 4(1): 41-47.
TEPGE, 2014. Tarımsal Ekonomi ve Politika Geliştirme Enstitüsü Müdürlügüu, Süt ve süt ürünleri raporu. Ulaşılabilir web adresi: http://www.tepge.gov.tr (Erişim Tarihi: 15 Haziran 2016).

Terzi, S., 2011. Finansal rasyolar yardımıyla finansal başarısızlık tahmini. Gıda sektöründe ampirik bir çalışma. Çukurova Üniversitesi İIBB Derg., 15 (1): 1-18.

Topcu, Y., 2005. A study on the meat cost and marketing margins of cattle fattening farms in Erzurum province. Turk J. Vet. Anim. Sci., 28 (6): 1007-1015.

Topcu, Y., 2008. Süt sığırcılığı işletmelerinde başarıyı etkileyen faktörlerin analizi. Erzurum İli Örneği. OMU Zir. Fak. Derg., 23 (1): 17-24.

Topcu, Y., 2010. Erzurum ili sığır besiciliği işletmelerinde girdi kullanımı ve üretim maliyeti üzerine bir araştırma. Atatürk Üniv. Ziraat Fak. Derg., 35(1-2): 65-73.

Topcu, Y., 2012. Uygulamalı Tarımsal Pazarlama Araştırma Teknikleri. Atatürk Üniversitesi Ziraat Fakültesi Tarım Ekonomisi Bölümü (Basılmamış Ders Notları), Erzurum.

Topcu, Y., 2015. Erzurum ili süt sığırcılığ1 işletmelerinin ekonomik analizi. Atatürk Üniversitesi BAP-2012/401 Proje Raporu, Erzurum.

Topcu, Y., Toparlak, M., Macit, M., 2016. Impacts of nutrition and feeding programs on farmers' management decisions affecting the success of dairy farms with culture breed cattle. Türk Tarım-Gıda Bilim ve Teknoloji Derg., 4(2): 6672.

Topcu, Y., 2018. Erzurum ili süt sığırcılığ işletmelerinin sermaye yapısına dayalı risk düzeyleri. YYÜ Tarım Bilimleri Derg., 28(2): 154-160.

TÜIK, 2017. Tarımsal ürünler istatistiği, İstatistiklerle Türkiye. Türkiye İstatistik Kurumu, Ankara. http://www.tuik.gov.tr (Erişim Tarihi: 15 Şubat 2017). 